\title{
Application of a Graphene Oxide-Carbon Paste Electrode for the Determination of Lead in Rainbow Trout from Central Europe
}

\author{
Sylwia Smarzewska • Witold Ciesielski
}

Received: 25 April 2014 / Accepted: 22 June 2014 / Published online: 22 July 2014

(C) The Author(s) 2014. This article is published with open access at Springerlink.com

\begin{abstract}
In the presented study, the content of lead in rainbow trout (Oncorhynchus mykiss) samples was examined. Rainbow trout were purchased in Prague (Czech Republic), Lodz (Poland) and Bratislava (Slovakia) from local fish shops and supermarkets belonging to popular chain stores. First, method for quantitative lead determination was developed with very good results $\left(R^{2}\right.$ at 0.9997 in the range of $1.0 \times 10^{-7}-7.0 \times$ $10^{-5} \mathrm{~mol} \mathrm{~L}^{-1}$ with limit of detection (LOD) and limit of quantification (LOQ) $2.18 \times 10^{-8}$ and $7.24 \times 10^{-8} \mathrm{~mol} \mathrm{~L}^{-1}$, respectively). Then, after mineralization, fish samples were analyzed using square wave anodic stripping voltammetry (SWASV) with a graphene oxide-carbon paste electrode (GO-CPE). Lead signals recorded on GO-CPE electrode were $15 \%$ higher than those obtained on bare CPE. The coefficient of variation (CV) was found to be below $5 \%$. The selectivity of the proposed method was evaluated by the addition of selected heavy metals (zinc, copper, mercury, cobalt, nickel, iron) as possible interferents. Results were confirmed with reference method.
\end{abstract}

Keywords Graphene oxide-carbon paste electrode · Rainbow trout $\cdot$ Lead determination $\cdot$ Square wave anodic stripping voltammetry

\section{Introduction}

Nowadays, countries all over the world face the problem of environmental pollution (Gallo and Almirall 2009; Ozden 2010). Many ecological and environmental changes emerge as a result of human agricultural and industrial activity (Pohl et al. 2009; Szyczewski et al. 2009). Significant emphasis is

S. Smarzewska $(\bowtie) \cdot$ W. Ciesielski

Department of Inorganic and Analytical Chemistry, Faculty of Chemistry, University of Lodz, Tamka 12, 91-403 Lodz, Poland

e-mail: sylwiasmarzewska@gmail.com placed on a wide range of chemical pollutants including heavy metals (Orecchio and Amorello 2010; Akinci et al. 2013; Struis et al. 2013). Aquatic pollution caused by heavy metals is particularly important due to their toxicity and accumulation capacity in organisms (Mendil et al. 2009; Shah et al. 2009). High levels of copper, lead and iron have been found to cause physiological changes in fish (Tarrio et al. 1991). On the other hand, fish are an important part of a balanced human diet as they contain a lot of proteins, vitamins, minerals and polyunsaturated fatty acids (Shrestha et al. 2013; Gogus and Smith 2010). Thus, the Nutrition Committee of the American Heart Association recommends eating fish at least twice a week to prevent cardiovascular diseases (Kris-Etherton et al. 2002). Rainbow trout (Oncorhynchus mykiss, in the family Salmonidae) are widely used as a farmed fish in many countries around the world due to its high nutritional value and rapid growth (Gall and Crandell 1992; Mashaie 2001). Nevertheless, fish can be a source of contaminants, such as highly toxic heavy metals. Hence, the determination of metals in fish is indeed indispensable and has drawn much attention in recent years (Sneddon et al. 2007; Sneddon and Vincent 2008; Zmozinski et al. 2013; Rofouei et al. 2012). Analysis of heavy metals in the various tissues of fish has been widely pursued using different methods, including electrochemistry (Bagheri et al. 2013), atomic absorption spectrophotometry (Al-Kahtani 2009; Fernandes et al. 2008), inductively coupled plasma mass spectrometry (Kalantzi et al. 2013; Schenone et al. 2014) and differential thermal analysis (Najafi et al. 2013). Among these methods, voltammetry is one of the preferred techniques due to its high sensitivity, simplicity and environmental friendliness. What is more, the properties of working electrodes used in voltammetry may be easily improved by simple modifications of electrode material or surface to achieve better stability, reproducibility and selectivity. In recent years, there has been a growing interest in the use of graphene and graphene oxide in various types of studies (Wang et al. 2013, 2014; Wu et al. 
2013) due to their promising properties (Chen et al. 2012) such as electron transport capability (Novoselov et al. 2005; Zhang et al. 2005), thermal and electrical conductivity (Balandin et al. 2008; Bolotin et al. 2008), mechanical stiffness (Lee et al. 2008) and unprecedented pliability and impermeability (Bunch et al. 2008; Lee et al. 2008). Graphene has been found to have a variety of applications, e.g. in sensors (Robinson et al. 2008), polymer composites (Domingues et al. 2011), transparent electrodes (Zhao et al. 2010; Blake et al. 2008) and hydrogen storage (Dimitrakakis et al. 2008). Up-to-date graphene and graphene oxide-modified carbon paste electrodes have been successfully applied for the determination of lead (Chen et al. 2013; Li et al. 2009; Wonsawat et al. 2012; Yang et al. 2011). In this paper, we report the application of a graphene oxide-modified carbon paste electrode for quantitative lead determination in rainbow trout muscle tissue under conditions of square wave anodic stripping voltammetry (SWASV). Both carbon paste electrodes and square wave voltammetry (SWV) are very popular in various fields of research. SW techniques owe their prevalence (Mirceski et al. 2011, 2013a, b; Pacheco et al. 2010; da Costa Fulgencio et al. 2014; Smarzewska et al. 2012, 2014; Snevajsova et al. 2010; Skrzypek et al. 2011; Nosal-Wiercinska and Dalmata 2009) to rapidity, simplicity and sensitivity, while carbon paste electrodes are cheap, stable and easy to modify (Svancara et al. 2005; Arvand and Kermanian 2013; Vazquez et al. 2012; Khaled et al. 2008; Kalcher 1990; Mailley et al. 2004; Fathirad et al. 2013).

\section{Material and Methods}

\section{Instrumentation}

A $\mu$ Autolab Type III/General Purpose Electrochemical System (GPES, version 4.9; Eco Chemie, Netherlands) was used with an M164 electrode stand (mtm-anko, Cracow, Poland) for all voltammetric measurements. Experiments were performed in a typical three-electrode system with a working GO-CPE or hanging mercury drop electrode (HMDE), a reference $\mathrm{Ag} /$ $\mathrm{AgCl}$ electrode $\left(3 \mathrm{~mol} \mathrm{~L}^{-1} \mathrm{KCl}\right)$ and a counter electrode $(\mathrm{Pt}$ wire). Measurements of $\mathrm{pH}$ were made using a $\mathrm{CP}-315 \mathrm{M} \mathrm{pH}$ meter (Elmetron, Poland) with a combined glass electrode.

\section{Solutions and Materials}

All the chemicals used (graphene oxide, graphite, paraffin oil, hydrochloric acid, perchloric acid, lead nitrate) were of analytical reagent grade and were purchased from Sigma-Aldrich. To prepare a graphene oxide-carbon paste electrode, $0.45 \mathrm{~g}$ of graphite powder, $0.05 \mathrm{~g}$ of graphene oxide and $150 \mu \mathrm{L}$ of paraffin oil were mixed and homogenized $(15 \mathrm{~min})$ and then packed into a piston-driven carbon paste electrode holder. Before each experiment, the surface of the $\mathrm{GO}-\mathrm{CPE}$ was refreshed by

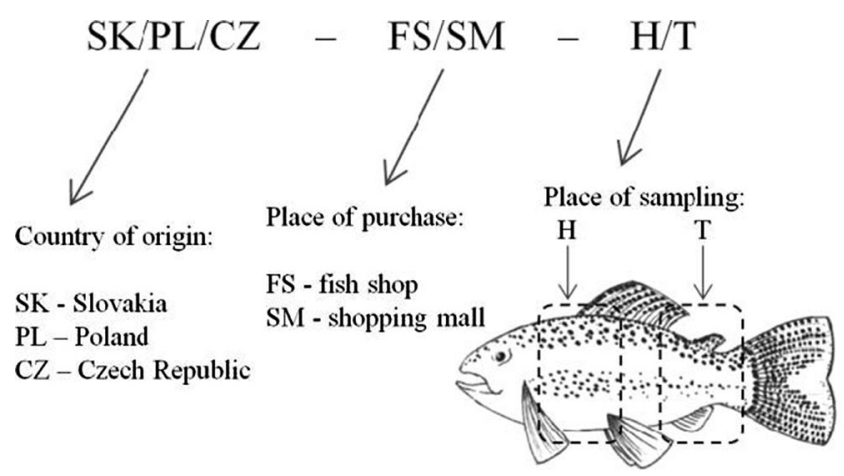

Scheme 1 Nomenclature of the samples

squeezing out a small portion of paste and polishing it with wet filter paper until a smooth surface was obtained.

\section{SWASV Analysis}

The general procedure adopted for obtaining adsorptive stripping voltammograms was as follows: the required aliquot of the analyzed working solution was placed in a cell containing a supporting electrolyte, deaerated by passing an argon stream for $600 \mathrm{~s}$, and then stirred at a chosen accumulation potential throughout the selected accumulation period. Following the pre-concentration step, the stirrer was stopped, and after $3 \mathrm{~s}$, scans were carried out over the range of -1.2 to $+1.0 \mathrm{~V}$ using the SW technique. All measurements were made in a standard $10 \mathrm{~mL}$ voltammetric cell, at room temperature. In order to ensure the reliability of the experiments, all samples were also investigated using an HMDE electrode.

Preparation of Real Samples

Rainbow trout were purchased in Prague (Czech Republic), Lodz (Poland) and Bratislava (Slovakia) from local fish shops

Table 1 Quantitative determination of lead in $0.1 \mathrm{M} \mathrm{HCl}$ by SWASV. Basic statistic data of the regression line

\begin{tabular}{lll}
\hline & GO-CPE & HMDE \\
\hline $\begin{array}{c}\text { Linear concentration range } \\
\quad\left(\mathrm{mol} \mathrm{L}^{-1}\right)\end{array}$ & $1.0 \times 10^{-7}-7.0 \times 10^{-5}$ & $1.0 \times 10^{-7}-5.0 \times 10^{-5}$ \\
$\begin{array}{c}\text { Slope of calibration } \\
\text { graph (A) }\left(\mathrm{L} \mathrm{mol}^{-1}\right)\end{array}$ & 4.01 & 3.39 \\
$\begin{array}{l}\text { SD of the slope } \\
\text { Intercept (A) }\end{array}$ & $4.6 \times 10^{-2}$ & $9.4 \times 10^{-3}$ \\
SD of the intercept & $2.72 \times 10^{-8}$ & $1.04 \times 10^{-8}$ \\
Correlation coefficient & $2.90 \times 10^{-9}$ & $6.62 \times 10^{-10}$ \\
$\begin{array}{l}\text { LOD (mol L } \\
\text { LOQ })\end{array}$ & 2.9997 & 0.9997 \\
Repeatability of peak & 1.8 & $5.87 \times 10^{-9}$ \\
$\quad$ current (CV) & $7.24 \times 10^{-8}$ & $1.96 \times 10^{-8}$ \\
Repeatability of peak & 0.65 & 2.9 \\
potential (CV) & & 1.2 \\
\hline
\end{tabular}


and large shopping malls belonging to popular chain stores. Fish samples were marked as shown in Scheme 1. Fish sample solutions were mineralized with a mixture of $\mathrm{HClO}_{4} / \mathrm{HNO}_{3}$ according to the method described in Sobhanardakani et al. (2012). After mineralization, the samples were filled up to volume (in 10-mL flasks) with 1:1 (v/v) water/0.1 $\mathrm{M} \mathrm{HCl}$ mixture (sample solutions). Then, the rainbow trout were analyzed using the standard addition method. For each fish sample, some preliminary studies were conducted to adjust the amount of standard solution.

\section{Linear Regression Equation, Calibration Curve and Sensitivity}

Calibration curves (described with the linear regression equation $y=b x+a$ ) were constructed by plotting lead peak current $(I, \mathrm{~A})$ against lead concentration $\left(C, \mathrm{~mol} \mathrm{~L}^{-1}\right)$ on the basis of 12 (GO-CPE) or 11 (HMDE) lead standard solutions for the concentration ranges $1.0 \times 10^{-7}-7.0 \times 10^{-5}$ and $1.0 \times 10^{-7}-$ $5.0 \times 10^{-5} \mathrm{~mol} \mathrm{~L}^{-1}$, respectively. To evaluate the sensitivity of SWASV analysis, the limit of detection (LOD) and the limit of quantification (LOQ) were determined. LOQ and LOD were calculated from the calibration curves as $k$ $\mathrm{SD} / b \quad(k=10$ for $\mathrm{LOQ}, k=3$ for $\mathrm{LOD}, \mathrm{SD}=$ standard deviation of the intercept, $b=$ slope of the calibration curve, dos Santos et al. 2004). For each concentration from the calibration curve, the coefficient of variation (CV) was calculated using the formula as follows: $\mathrm{CV}=\left(\mathrm{SD} \times C_{\text {ave }}{ }^{-1}\right) \times 100 \%$, where $C_{\mathrm{ave}}$ represents the average lead concentration calculated from the linear regression equation and SD is the standard deviation of the calculated concentrations.
Precision and Accuracy

The precision of the developed method was evaluated for the GO-CPE by the coefficient of variation of three intra- and inter-day replicate measurements of CZ-FS-T and $\mathrm{SK}-\mathrm{FS}-\mathrm{H}$ samples done within 1 day and for three consecutive days, respectively. The accuracy of the SWASV method was determined by spike recovery. Appropriate amounts of lead nitrate standard solution were added into distilled water. Spiked distilled water solutions were mineralized and analyzed using the standard addition method under the experimental conditions as for fish samples described in "SWASV Analysis" and "Preparation of Real Samples" sections. The recovery of each spiked solution was calculated using the following formula: Recovery $(\%)=100+\left[\left(C_{\mathrm{ave}}-C_{\mathrm{spi}}\right) /\left(C_{\mathrm{spi}}\right)\right] \times 100$, where $C_{\text {spi }}$ is the actual lead concentration in a spiked sample and $C_{\text {ave }}$ is the average lead concentration calculated using the least-squares regression method on the basis of standard addition method results.

\section{Results and Discussion}

Influence of SW Parameters

Research work was started with the selection of supporting electrolyte. First, various supporting electrolytes were tested (BR buffers, acetate buffer, ammonia buffer, hydrochloric acid, nitric acid) in the $\mathrm{pH}$ range $0.5-10$. The highest lead signals were recorded in acidic solutions $\mathrm{pH} 1.0-3.0$. Although the recorded signals in $\mathrm{pH} 2.0$ were 3-8\% higher
Fig. 1 SWASV voltammograms of lead in $0.1 \mathrm{M} \mathrm{HCl}$ on $\mathrm{GO}-\mathrm{CPE}$ and HMDE, lead concentrations (in $\mu \mathrm{mol} \mathrm{L}{ }^{-1}$ ): $a 0.10, b 0.50, c$ 1.0, d 3.0, e 5.0, f 7.0, g 10.0, $h$ $30.0, i 50.00$ and $j 70.0$. The other experimental conditions were as follows: amplitude $\left(E_{\mathrm{sw}}\right)=50 \mathrm{mV}$, step potential $(\Delta E)=8 \mathrm{mV}$, frequency $(f)=8 \mathrm{~Hz}$, accumulation potential $\left(E_{\text {acc }}\right)=-0.9 \mathrm{~V}$ and accumulation time $\left(t_{\text {acc }}\right)=90 \mathrm{~s}$
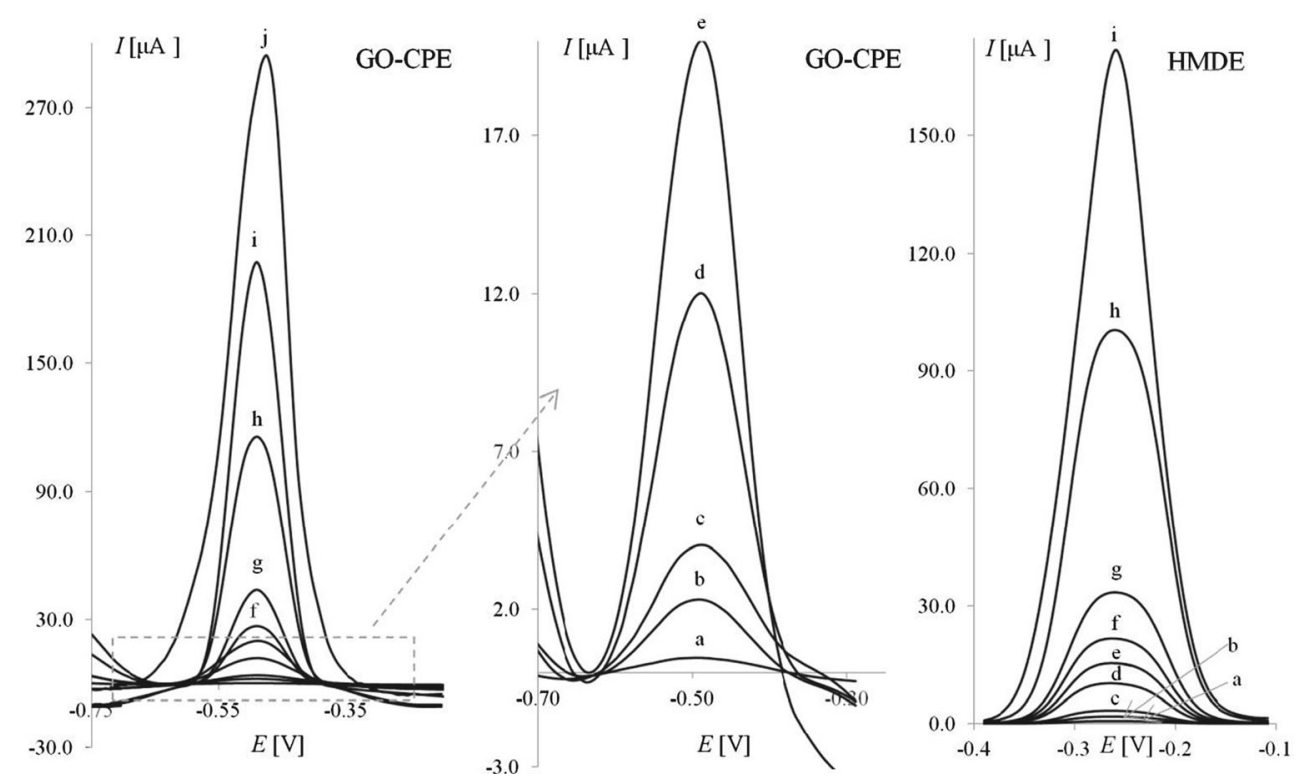
Table 2 Recovery and precision of the lead peak currents at various lead concentrations

\begin{tabular}{|c|c|c|c|c|c|c|c|c|}
\hline \multirow{2}{*}{$\begin{array}{l}\text { Concentration } \\
\text { given }\left(\mu \mathrm{mol} \mathrm{L}{ }^{-1}\right)\end{array}$} & \multicolumn{4}{|l|}{ GO-CPE } & \multicolumn{4}{|l|}{ HMDE } \\
\hline & $\begin{array}{l}\text { Concentration found } \\
\left.(\mu \mathrm{mol} \mathrm{L})^{-1}\right)\end{array}$ & $\begin{array}{l}\text { Confidence limit } \\
\left(\times 10^{-6}\right)\end{array}$ & $\begin{array}{l}\mathrm{CV} \\
(\%)\end{array}$ & $\begin{array}{l}\text { Recovery } \\
(\%)\end{array}$ & $\begin{array}{l}\text { Concentration found } \\
\left.(\mu \mathrm{mol} \mathrm{L})^{-1}\right)\end{array}$ & $\begin{array}{l}\text { Confidence limit } \\
\left(\times 10^{-6}\right)\end{array}$ & $\begin{array}{l}\mathrm{CV} \\
(\%)\end{array}$ & $\begin{array}{l}\text { Recovery } \\
(\%)\end{array}$ \\
\hline 0.1000 & 0.1030 & 0.0028 & 2.42 & 102.9 & 0.1019 & 0.0096 & 8.30 & 101.9 \\
\hline 0.3000 & 0.288 & 0.016 & 4.76 & 96.1 & 0.2898 & 0.0097 & 2.95 & 96.6 \\
\hline 0.500 & 0.511 & 0.017 & 2.98 & 102.2 & 0.509 & 0.036 & 6.33 & 101.8 \\
\hline 0.700 & 0.712 & 0.031 & 3.87 & 101.7 & 0.698 & 0.047 & 6.01 & 99.7 \\
\hline 1.000 & 1.036 & 0.011 & 0.96 & 103.6 & 0.987 & 0.077 & 6.91 & 98.7 \\
\hline 3.00 & 3.02 & 0.23 & 6.63 & 100.6 & 2.87 & 0.089 & 2.73 & 95.7 \\
\hline 5.00 & 5.07 & 0.13 & 2.32 & 101.4 & 4.98 & 0.29 & 5.18 & 99.6 \\
\hline 7.00 & 7.23 & 0.17 & 2.08 & 103.3 & 7.03 & 0.30 & 3.78 & 100.4 \\
\hline 10.00 & 10.23 & 0.43 & 3.73 & 102.3 & 9.90 & 0.47 & 4.16 & 99.0 \\
\hline 30.0 & 29.0 & 2.6 & 7.94 & 96.7 & 29.1 & 1.6 & 4.85 & 97.0 \\
\hline 50.0 & 49.7 & 1.3 & 2.37 & 99.4 & 50.9 & 1.2 & 2.05 & 101.8 \\
\hline 70.00 & 70.57 & 0.28 & 0.35 & 100.8 & - & - & - & - \\
\hline
\end{tabular}

(but had slightly worse morphology) than those in $\mathrm{pH} 1.0$, in the preliminary studies, it was found that the $\mathrm{pH}$ of the mineralized samples was around 1.0; therefore, to ensure reliable and comparable results, $\mathrm{pH} 1.0$ was chosen for all the experiments. Next, several supporting electrolyte solutions were examined at pH 1.0 in detail (hydrochloric acid, nitric acid, sulfuric acid and perchloric acid) with various techniques (LSV, DPV, SWV). The strongest, wellshaped signals were obtained in $0.1 \mathrm{M} \mathrm{HCl}$ solution for all the used techniques. Considering sensitivity and signal shape, SWASV was chosen for analytical purposes. Then, the influence of SWASV parameters on lead peak current was examined. During adjusting the above-mentioned parameters, each parameter was changed while the others were kept constant using $5 \times$ $10^{-6} \mathrm{~mol} \mathrm{~L}^{-1}$ lead concentration. These parameters have correlative influence on the measured peak potential and current, but in this study, only the general tendencies were investigated. The studied square wave amplitude, step potential, frequency, accumulation potential and accumulation time ranges were $5-200 \mathrm{mV}, 1-25 \mathrm{mV}$, $8-200 \mathrm{~Hz},-2.0$ to $-0.6 \mathrm{~V}$ and $5-300 \mathrm{~s}$, respectively. The optimized values were as follows: $E_{\mathrm{sw}}=50 \mathrm{mV}$, $\Delta E=8 \mathrm{mV}, f=8 \mathrm{~Hz}, E_{\mathrm{acc}}=-0.9 \mathrm{~V}$ and $t_{\mathrm{acc}}=90 \mathrm{~s}$.
Validation of the Developed Method

First, it is worth mentioning that lead signals recorded on GOCPE electrode in optimized conditions were $15 \%$ higher than those obtained on bare CPE. In our opinion, according to graphene oxide content in paste, modified electrode has better conductivity (as explained in the "Introduction" section). That was confirmed by resistance measurements; measured resistance for CPE and GO-CPE was equal to 235 and $147 \Omega$, respectively. In order to validate the developed SWASV analytical method, linearity, precision, accuracy, sensitivity and stability were evaluated. Linear regression equations, linearity, LOD and LOQ are presented in Table 1. Linearity is given by the correlation coefficient $\left(R^{2}\right)$ and shows very good correlation with $R^{2}$ at 0.9997 in the range of $1.0 \times 10^{-7}-7.0 \times$ $10^{-5} \mathrm{~mol} \mathrm{~L}^{-1}$ (GO-CPE). The LOD and LOQ were $2.18 \times$ $10^{-8}$ and $7.24 \times 10^{-8} \mathrm{~mol} \mathrm{~L}^{-1}$, respectively. The voltammograms recorded on the GO-CPE and HMDE during calibration curve examination are shown in Fig. 1.

Repeatability of the procedure was estimated with three measurements at the same lead concentration. In order to check the correctness of the method, precision (expressed by $\mathrm{CV}$ ) and recovery of the method were also calculated for different concentrations within the linear range (Table 2).
Table 3 Precision test of the SWASV analysis on GO-CPE

\begin{tabular}{lcccc}
\hline Sample & Found $(\mathrm{mg} / 100 \mathrm{~g})$ & & & \\
\cline { 2 - 5 } & $\begin{array}{l}\text { Intra-day measurements } \\
(\text { average } \pm \mathrm{SD}, n=3)\end{array}$ & $\mathrm{CV}$ & $\begin{array}{l}\text { Inter-day measurements } \\
\text { (average } \pm \mathrm{SD}, n=3)\end{array}$ & $\mathrm{CV}$ \\
\hline SK-FS-H & $0.03685 \pm 0.00077$ & 2.09 & $0.03663 \pm 0.00050$ & 1.37 \\
CZ-FS-T & $0.1145 \pm 0.0018$ & 1.56 & $0.1130 \pm 0.0053$ & 4.68 \\
\hline
\end{tabular}


Fig. 2 SWASV voltammograms of lead determination in spiked samples using standard addition method. Sample 1: s1 sample $\left(1.0 \mu \mathrm{mol} \mathrm{L}^{-1}\right)$ and $a 1 / b 1 / c 1$ standard additions $\left(1.0 \times 10^{-8} \mathrm{~mol}\right) ;$ sample 2 $\left(5.0 \mu \mathrm{mol} \mathrm{L}{ }^{-1}\right): s 2$ sample and $a 2 / b 2 / c 2$ standard additions $\left(5.0 \times 10^{-8} \mathrm{~mol}\right)$ at $\mathrm{GO}-\mathrm{CPE}$ and HMDE in $0.01 \mathrm{M} \mathrm{HCl}$. Experimental conditions are the same as those in Fig. 1
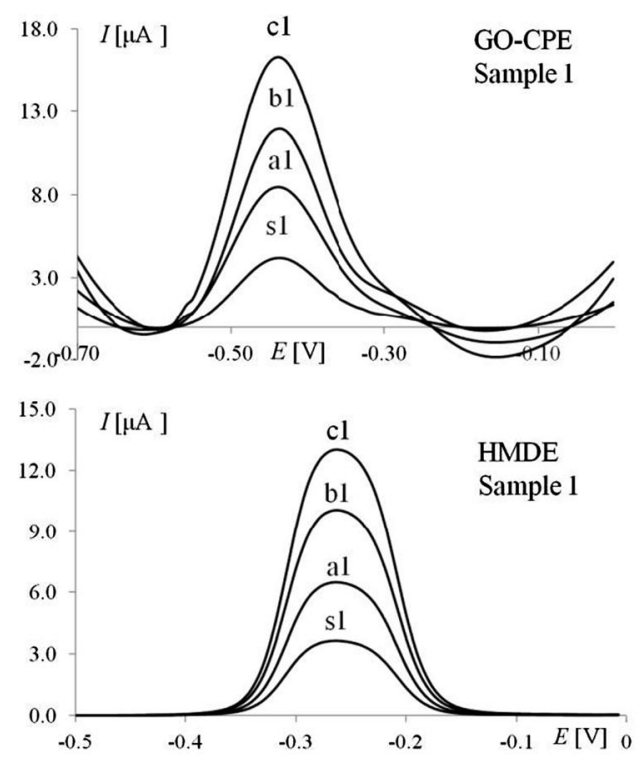

GO-CPE

Sample 2
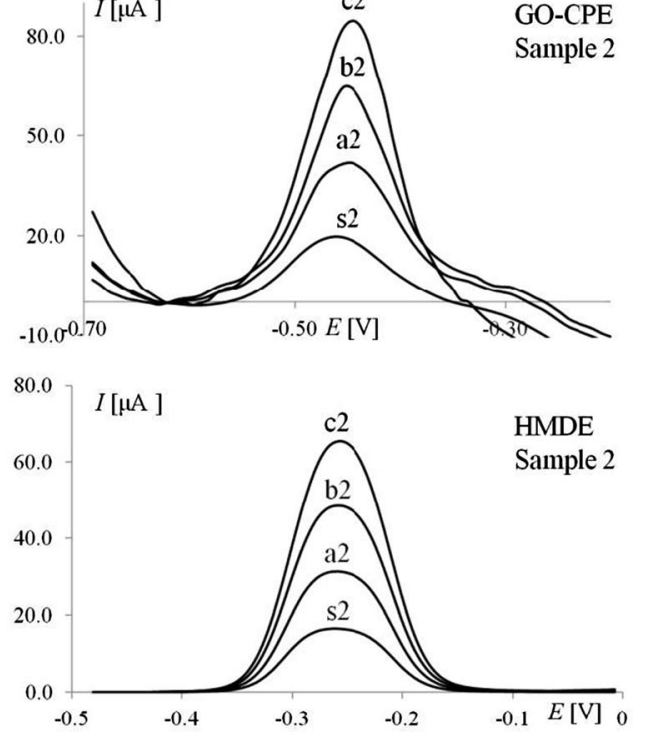

Variations (CV) of the amount of lead found in samples SK-FS-H and CZ-FS-T were 1.37-4.68 \%, indicating that the lead contained in the mineralized samples was stable for at least $72 \mathrm{~h}$. Coefficient of variations for intra- and inter-day measurements is shown in Table 3. Overall variations did not exceed $2.1 \%$ for intra-day runs and $4.7 \%$ for inter-day runs.

Recoveries were also determined for the two spiked distilled water solutions. Each water sample was contaminated by the addition of a specified concentration of lead. An aliquot of each sample was added into the electrochemical cell, and recovery curves were constructed by the standard addition method, using the optimized parameters. Three replicate analyses were made for each sample. The least-squares regression method was used to evaluate the recovery percentage. The obtained SWV responses are shown in Fig. 2. The calculated recoveries of the analyzed samples varied in the range of 98.7-109.6\% (Table 4), demonstrating that the developed SWASV method was precise and accurate.

\section{Analysis of Rainbow Trout Samples}

Analysis of real samples was preceded by testing of the used solutions for lead content. Samples of distilled water, supporting electrolyte and $\mathrm{HClO}_{4} / \mathrm{HNO}_{3}$ mixture were mineralized and analyzed as described in "SWASV Analysis" and
"Preparation of Real Samples" sections. Lead was not detected in any of the samples. As described in the "Material and Methods" section, fish samples were mineralized and then analyzed using the standard addition method. As can be seen in Fig. 3, where sample voltammograms are shown, in each experiment, three additions of the standard were made. Amounts of the standard lead solution varied between samples from $1 \times 10^{-8}$ to $1 \times 10^{-7} \mathrm{~mol}$ due to differences in lead content between fish samples (for example, additions contained $2 \times$ $10^{-8}$ and $8 \times 10^{-8} \mathrm{~mol}$ of lead for CZ-FS-T and PL-SM-H samples, respectively). The lead content calculated for rainbow trout samples is shown in Table 5. Obtained results (for both electrodes) were compared with popular statistical tests ( $F$ test, Student's $t$ test). As it was calculated from $F$ test, standard deviation values differ significantly in terms of precision only for sample CZ-SM-H. Student's $t$ test indicate that only results for samples SK-FS-H and SK-FS-T differ in a statistically significant way in terms of accuracy. Additionally, a linear relationship between lead content and fish length was observed. This relationship can be described with the following equation: $m_{\mathrm{Pb}}(\mathrm{mg} / 100 \mathrm{~g})=0.046 l_{\text {fish }}(\mathrm{cm})-0.0597$, where $m_{\mathrm{Pb}}$ is the found amount of lead (in $\mathrm{mg}$ for $100 \mathrm{~g}$ of fish) and $l_{\text {fish }}$ is fish length. This relationship is probably due to the fact that the longer a fish lives (the length of fish increases with age), the longer is the time of lead accumulation.

Table 4 Determination of lead in spiked samples

\begin{tabular}{|c|c|c|c|c|c|c|c|c|}
\hline \multirow{2}{*}{$\begin{array}{l}\text { Added } \\
\left(\mu \mathrm{mol} \mathrm{L}{ }^{-1}\right)\end{array}$} & \multicolumn{4}{|l|}{$\mathrm{GO}-\mathrm{CPE}$} & \multicolumn{4}{|l|}{ HMDE } \\
\hline & $\begin{array}{l}\text { Found } \\
\left(\mu \mathrm{mol} \mathrm{L}{ }^{-1}\right)\end{array}$ & $\begin{array}{l}\text { Confidence limit } \\
\left(\times 10^{-6}\right)\end{array}$ & $\begin{array}{l}\text { Precision } \\
\mathrm{CV}\end{array}$ & $\begin{array}{l}\text { Recovery } \\
(\%)\end{array}$ & $\begin{array}{l}\text { Found } \\
\left(\mu \mathrm{mol} \mathrm{L} \mathrm{L}^{-1}\right)\end{array}$ & $\begin{array}{l}\text { Confidence limit } \\
\left(\times 10^{-6}\right)\end{array}$ & $\begin{array}{l}\text { Precision } \\
\mathrm{CV}\end{array}$ & $\begin{array}{l}\text { Recovery } \\
(\%)\end{array}$ \\
\hline 1.000 & 1.026 & 0.027 & 2.35 & 102.9 & 1.096 & 0.048 & 3.84 & 109.6 \\
\hline 5.000 & 5.02 & 0.14 & 2.43 & 100.4 & 4.936 & 0.076 & 1.36 & 98.7 \\
\hline
\end{tabular}


Fig. 3 SWASV voltammograms of lead determination in rainbow trout muscles using standard addition method (sample CZ-FS$T$ : $s 1$ sample and $a 1 / b 1 / c 1$ standard additions; sample $P L-S M-H:$ s2 sample and $a 2 / b 2 / c 2$ standard additions) on GO-CPE and HMDE in $0.01 \mathrm{M}$ $\mathrm{HCl}$. Experimental conditions are the same as those in Fig. 1
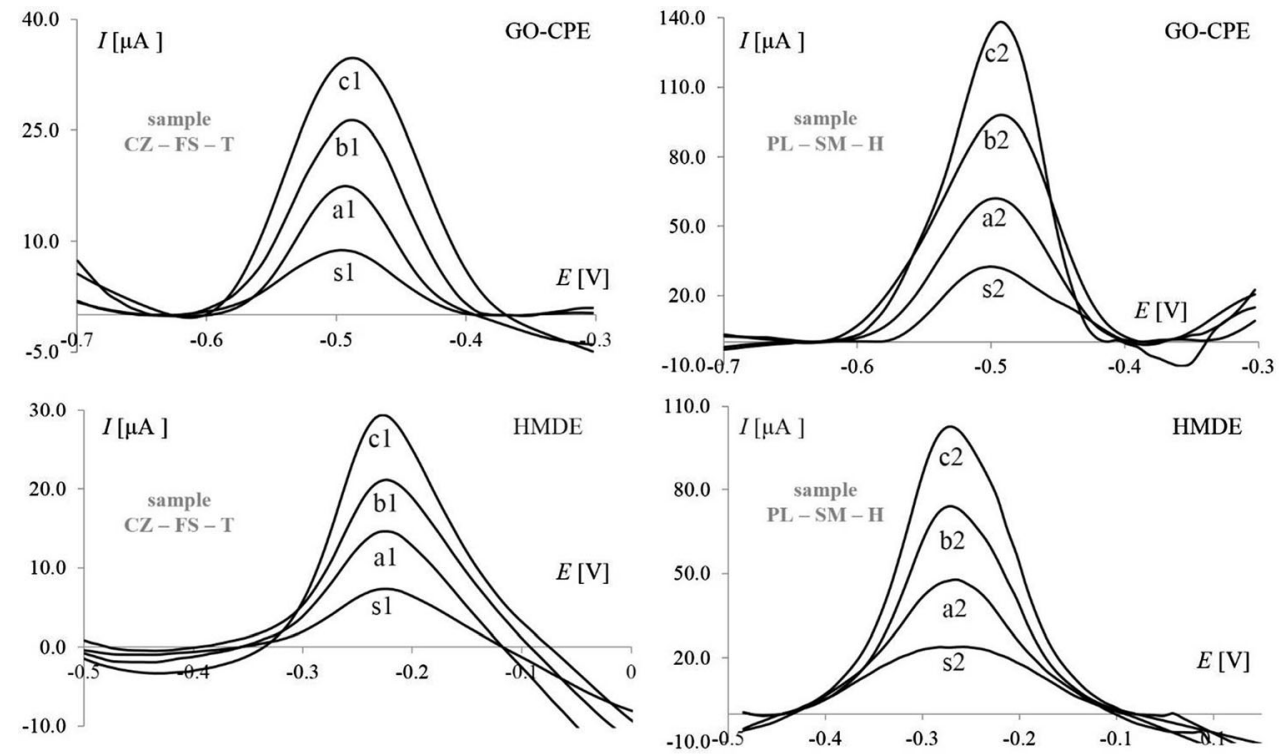

Selectivity of the Method

The selectivity of the developed method was evaluated by the addition of possible interferents-heavy metals (zinc, mercury, cadmium, copper, nickel and cobalt). To $5 \times 10^{-6} \mathrm{~mol} \mathrm{~L}^{-1}$ lead, solutions of interferents were added at concentration ratios of 1:1, 1:2 and 1:10. The responses were compared to those obtained for the pure standard lead solution. Only the presence of cadmium caused significant enhancement of the background current (without influencing the lead peak current). The other studied substances did not interfere with the determination of lead under the working conditions used (signal change $<3 \%$ ).

\section{Conclusions}

Graphene oxide-modified carbon paste electrode was used in combination with the SWASV technique to develop a novel and alternative electroanalytical method for lead determination in real samples. The GO-modified electrode exhibits stability, reproducibility and favourable properties for quantitative lead determination. Micromolar concentrations of lead were determined by square wave anodic stripping voltammetry at the surface of the GO-CPE with a $\mathrm{CV}$ smaller than $5 \%$, recoveries in the range of 96.1 to $103.6 \%$ and a LOQ of $7.24 \times 10^{-8} \mathrm{~mol} \mathrm{~L}^{-1}$. The important point that should be emphasized is the environmental friendliness and/or low cost of the GO-CPE in comparison to e.g. metal film electrodes $(\mathrm{Bi}, \mathrm{Hg}, \mathrm{Au})$ frequently used in lead
Table 5 Contents of lead in rainbow trout

\begin{tabular}{|c|c|c|c|c|c|c|}
\hline \multirow[t]{2}{*}{ Sample } & \multicolumn{3}{|l|}{ GO-CPE } & \multicolumn{3}{|l|}{ HMDE } \\
\hline & $\begin{array}{l}\text { Found } \\
(\mathrm{mg} / 100 \mathrm{~g})\end{array}$ & $\begin{array}{l}\text { Confidence } \\
\text { limit }\left(\times 10^{-2}\right)\end{array}$ & $\mathrm{CV}$ & $\begin{array}{l}\text { Found } \\
(\mathrm{mg} / 100 \mathrm{~g})\end{array}$ & $\begin{array}{l}\text { Confidence } \\
\text { limit }\left(\times 10^{-2}\right)\end{array}$ & $\mathrm{CV}$ \\
\hline CZ-SM-H & 0.426 & 3.82 & 4.92 & 0.428 & 0.299 & 0.62 \\
\hline CZ-SM-T & 0.417 & 3.28 & 4.95 & 0.430 & 1.77 & 3.65 \\
\hline $\mathrm{CZ}-\mathrm{FS}-\mathrm{H}$ & 0.121 & 0.621 & 4.52 & 0.119 & 0.327 & 2.43 \\
\hline CZ-FS-T & 0.114 & 0.203 & 1.56 & 0.110 & 0.529 & 4.22 \\
\hline PL-SM-H & 0.628 & 2.43 & 3.41 & 0.612 & 2.16 & 3.12 \\
\hline PL-SM-T & 0.608 & 3.51 & 4.90 & 0.601 & 1.75 & 2.58 \\
\hline PL-FS-H & 0.167 & 1.12 & 4.94 & 0.183 & 0.982 & 4.74 \\
\hline PL-FS-T & 0.153 & 0.352 & 2.03 & 0.145 & 0.796 & 4.82 \\
\hline SK-SM-H & 0.066 & 0.0586 & 0.78 & No data & & \\
\hline SK-SM-T & 0.065 & 0.225 & 3.05 & No data & & \\
\hline SK-FS-H & 0.036 & 0.0873 & 2.09 & 0.041 & 0.216 & 4.63 \\
\hline SK-FS-T & 0.036 & 0.994 & 2.41 & 0.045 & 0.170 & 3.33 \\
\hline
\end{tabular}


determination. Furthermore, GO-CPE offers also a simple and rapid cleaning procedure, which allows for the use of the electrode for a long time with reproducible responses. The other benefits of the developed method such as rapidity and simplicity were proven by the successful application of the method to rainbow trout analysis following simple preparation of samples. It is worth noting that the results obtained on the GO-CPE are comparable with those obtained on the HMDE. The GO-CPE exhibits small variation coefficients, very good recoveries and a linear range even longer than that obtained for the HMDE. Such behaviour proves that mercury electrodes and metal film electrodes can be successfully replaced by environmentally friendly carbon electrodes with graphene oxide modifications, as the sensitivity exhibited by GO-CPE electrode is sufficient for real sample analysis.

Acknowledgments Financial support of the grant 506/1123 from the Ministry of Science and Higher Education is gratefully acknowledged.

Conflict of Interest Sylwia Smarzewska declares that she has no conflict of interest. Witold Ciesielski declares that he has no conflict of interest. This article does not contain any studies with human or animal subjects.

Open Access This article is distributed under the terms of the Creative Commons Attribution License which permits any use, distribution, and reproduction in any medium, provided the original author(s) and the source are credited.

\section{References}

Akinci G, Guven DE, Ugurlu SK (2013) Assessing pollution in Izmir Bay from rivers in western Turkey: heavy metals. Environ Sci Process Impact 15:2252-2262

Al-Kahtani MA (2009) Accumulation of heavy metals in tilapia fish (Oreochromis niloticus) from Al-Khadoud Spring, Al-Hassa, Saudi Arabia. Am J Appl Sci 6:2024-2029

Arvand M, Kermanian M (2013) Potentiometric determination of aluminum in foods, pharmaceuticals, and alloys by AlMCM-41-modified carbon paste electrode. FoAnal Methods 6:578-586

Bagheri H, Afkhami A, Khoshsafar H, Rezaei M, Shirzadmehr A (2013) Simultaneous electrochemical determination of heavy metals using a triphenylphosphine/MWCNTs composite carbon ionic liquid electrode. Sens Actuators B 186:451-460

Balandin AA, Ghosh S, Bao WZ, Calizo I, Teweldebrhan D, Miao F, Lau CN (2008) Superior thermal conductivity of single-layer graphene. Nano Lett 8:902-907. doi:10.1021/N10731872

Blake P, Brimicombe PD, Nair RR, Booth TJ, Jiang D, Schedin F et al (2008) Graphene-based liquid crystal device. Nano Lett 8:1704-1708

Bolotin KI et al (2008) Ultrahigh electron mobility in suspended graphene. Solid State Commun 146:351-355. doi:10.1016/j.ssc. 2008.02.024

Bunch JS, Verbridge SS, Alden JS, van der Zande AM, Parpia JM, Craighead HG, McEuen PL (2008) Impermeable atomic membranes from graphene sheets. Nano Lett 8:2458-2462. doi:10.1021/ n1801457b

Chen D, Feng HB, Li JH (2012) Graphene oxide: preparation, functionalization, and electrochemical applications. Chem Rev 112:6027-6053. doi:10.1021/Cr300115g
Chen M, Chao M, Ma X (2013) Poly(crystal violet)/graphene-modified electrode for the simultaneous determination of trace lead and cadmium ions in water samples. J Appl Electrochem 44:337-344

da Costa Fulgencio AC, Saczk AA, de Oliveira MF, Okumura LL (2014) New voltammetry-based analytical method for indirect determination of procymidone in Brazilian apples. Food Anal Methods 7:3138

Dimitrakakis GK, Tylianakis E, Froudakis GE (2008) Pillared graphene: a new 3-D network nanostructure for enhanced hydrogen storage. Nano Lett 8:3166-3170

Domingues SH, Salvatierra RV, Oliveira MM, Zarbin AJG (2011) Transparent and conductive thin films of graphene/polyaniline nanocomposites prepared through interfacial polymerization. Chem Commun 47:2592-2594

dos Santos LBO, Abate G, Masini JC (2004) Determination of atrazine using square wave voltammetry with the hanging mercury drop electrode (HMDE). Talanta 62:667-674

Fathirad F, Afzali D, Mostafavi A, Shamspur T, Fozooni S (2013) Fabrication of a new carbon paste electrode modified with multiwalled carbon nanotube for stripping voltammetric determination of bismuth(III). Electrochim Acta 103:206-210. doi:10.1016/j. electacta.2013.03.162

Fernandes C, Fontainhas-Fernandes A, Cabral D, Salgado MA (2008) Heavy metals in water, sediment and tissues of Liza saliens from Esmoriz-Paramos lagoon. Port Environ Monit Assess 136:267-275

Gall GAE, Crandell PA (1992) The rainbow trout. Aquaculture 100:1-10

Gallo JM, Almirall JR (2009) Elemental analysis of white cotton fiber evidence using solution ICP-MS and laser ablation ICP-MS (LAICP-MS). Forensic Sci Int 190:52-57

Gogus U, Smith C (2010) n-3 omega fatty acids: a review of current knowledge. Int J Food Sci Technol 45:417-436

Kalantzi I, Shimmield TM, Pergantis SA, Papageorgiou N, Black KD, Karakassis I (2013) Heavy metals, trace elements and sediment geochemistry at four Mediterranean fish farms. Sci Total Environ 444:128-137

Kalcher K (1990) Chemically modified carbon paste electrodes in voltammetric analysis. Electroanalysis 2:419-433

Khaled E, Hassan HNA, Girgis A, Metelka R (2008) Construction of novel simple phosphate screen-printed and carbon paste ionselective electrodes. Talanta 77:737-743

Kris-Etherton PM, Harris WS, Appel LJ (2002) Fish consumption, fish oil, omega-3 fatty acids, and cardiovascular disease. Circulation 106:2747-2757

Lee C, Wei X, Kysar JW, Hone J (2008) Measurement of the elastic properties and intrinsic strength of monolayer graphene. Science 321:385-388. doi:10.1126/science.1157996321/5887/385 [pii]

Li J, Guo S, Zhai Y, Wang E (2009) High-sensitivity determination of lead and cadmium based on the Nafion-graphene composite film. Anal Chim Acta 649:196-201. doi:10.1016/j.aca.2009.07.030

Mailley P, Cummings EA, Mailley S, Cosnier S, Eggins BR, McAdams E (2004) Amperometric detection of phenolic compounds by polypyrrolebased composite carbon paste electrodes. Bioelectrochemistry 63:291296. doi:10.1016/j.bioelechem.2003.11.008

Mashaie MA (2001) Manual of trout farming. Nourbakhsh, Tehran, pp $17-26$

Mendil D, Celik F, Tuzen M, Soylak M (2009) Assessment of trace metal levels in some moss and lichen samples collected from near the motorway in Turkey. J Hazard Mater 166:1344-1350

Mirceski V, Guziejewski D, Ciesielski W (2011) Theoretical treatment of a cathodic stripping mechanism of an insoluble salt coupled with a chemical reaction in conditions of square wave voltammetry. Application to 6-mercaptopurine-9-D-riboside in the presence of Ni(II). Electroanalysis 23:1365-1375

Mirceski V, Guziejewski D, Lisichkov K (2013a) Electrode kinetic measurements with square-wave voltammetry at a constant scan rate. Electrochim Acta 114:667-673 
Mirceski V, Laborda E, Guziejewski D, Compton RG (2013b) New approach to electrode kinetic measurements in square-wave voltammetry. Amplitude-based quasireversible maximum. Anal Chem 85:5586-5594

Najafi E, Aboufazeli F, LotfiZadehZhad HR, Sadeghi O, Amani V (2013) A novel magnetic ion imprinted nano-polymer for selective separation and determination of low levels of mercury(II) ions in fish samples. Food Chem 141:4040-4045

Nosal-Wiercinska A, Dalmata G (2009) Application of the catalytic properties of $N$-methylthiourea to the determination of $\operatorname{In}(\mathrm{III})$ at low levels by square wave voltammetry. Monatsh Chem 140: $1421-1424$

Novoselov KS et al (2005) Two-dimensional gas of massless Dirac fermions in graphene. Nature 438:197-200. doi:10.1038/ Nature 04233

Orecchio S, Amorello D (2010) Platinum and rhodium associated with the leaves of Nerium oleander L. Analytical method using voltammetry; assessment of air quality in the Palermo (Italy) area. J Hazard Mater 174:720-727

Ozden O (2010) Micro, macro mineral and proximate composition of Atlantic bonito and horse mackerel: a monthly differentiation. Int $\mathrm{J}$ Food Sci Technol 45:578-586

Pacheco WF, Doyle A, Duarte DRA, Ferraz CS, Farias PAM, Aucelio RQ (2010) Square-wave adsorptive stripping voltammetry for trace determination of dimoxystrobin and azoxystrobin in potatoes and grapes. Food Anal Methods 3:205-210

Pohl P, Sergie I, Stecka H (2009) Determination and fractionation of metals in honey. Crit Rev Anal Chem 39:276-288

Robinson JT, Perkins FK, Snow ES, Wei ZQ, Sheehan PE (2008) Reduced graphene oxide molecular sensors. Nano Lett 8:3137-3140

Rofouei MK, Rezaei A, Masteri-Farahani M, Khani H (2012) Selective extraction and preconcentration of ultra-trace level of mercury ions in water and fish samples using $\mathrm{Fe}_{3} \mathrm{O}_{4}$-magnetite-nanoparticles functionalized by triazene compound prior to its determination by inductively coupled plasma-optical emission spectrometry. Anal Methods 4:959-966

Schenone NF, Avigliano E, Goessler W, Fernandez Cirelli A (2014) Toxic metals, trace and major elements determined by ICP MS in tissues of Parapimelodus valenciennis and Prochilodus lineatus from Chascomus Lake, Argentina. Microchem J 112:127-131

Shah AQ, Kazi TG, Arain MB, Baig J, Afridi HI, Jamali MK, Jalbani N, Kandhro GA (2009) Optimization of ultrasonic-assisted acid extraction of mercury in muscle tissues of fishes using multivariate strategy. J AOAC Int 92:1580-1586

Shrestha B, Javonillo R, Burns JR, Pirgerc Z, Vertes A (2013) Comparative local analysis of metabolites, lipids and proteins in intact fish tissues by LAESI mass spectrometry. Analyst 138:3444-3449

Skrzypek S, Mirceski V, Smarzewska S, Guziejewski D, Ciesielski W (2011) Voltammetric study of 2-guanidinobenzimidazole: electrode mechanism and determination at mercury electrode. Collect Czechoslov Chem Commun 76:1699-1715

Smarzewska S, Skrzypek S, Ciesielski W (2012) Voltammetric determination of proguanil in Malarone and spiked urine with a renewable silver amalgam film electrode. Electroanalysis 24:1966-1972

Smarzewska S, Metelka R, Guziejewski D, Skowron M, Skrzypek S, Brycht M, Ciesielski W (2014) Voltammetric behaviour and quantitative determination of pesticide iminoctadine. Anal Methods 6: 1884-1889. doi:10.1039/C3AY42038H

Sneddon J, Vincent MD (2008) ICP-OES and ICP-MS for the determination of metals: application to oysters. Anal Lett 41:1291-1303
Sneddon J, Rode PW, Hamilton MA, Pingeli S, Hagen JP (2007) Determination of metals in seafood and fish in Southwest Louisiana. Appl Spectrosc Rev 42:23-42

Snevajsova P, Tison L, Brozkova I, Vytrasova J, Metelka R, Vytras K (2010) Carbon paste electrode for voltammetric detection of a specific DNA sequence from potentially aflatoxigenic Aspergillus species. Electrochem Commun 12:106-109. doi:10.1016/j.elecom. 2009.10.047

Sobhanardakani S, Tayebi L, Farmany A, Cheraghi M (2012) Analysis of trace elements $(\mathrm{Cu}, \mathrm{Cd}$, and $\mathrm{Zn})$ in the muscle, gill, and liver tissues of some fish species using anodic stripping voltammetry. Environ Monit Assess 184:6607-6611

Struis RPWJ, Pasquali M, Borgese L, Gianoncelli A, Gelfi M, Colombi P, Thiaudiere D, Depero LE, Rizzo G, Bontempi E (2013) Inertisation of heavy metals in municipal solid waste incineration fly ash by means of colloidal silica - a synchrotron X-ray diffraction and absorption study. RSC Adv 3:14339-14351

Svancara I, Baldrianova L, Vlcek M, Metelka R, Vytras K (2005) A role of the plating regime in the deposition of bismuth films onto a carbon paste electrode. Microsc Study Electroanalysis 17:120-126

Szyczewski P, Siepak J, Niedzielski P, Sobczynski T (2009) Research on heavy metals in Poland. Pol J Environ Stud 18:755-768

Tarrio J, Jaffor M, Ashraf M (1991) Levels of selected heavy metals in commercial fish rom five fresh water lake Pakistan. Toxicol Environ Chem 33:133-140

Vazquez D, Tascon M, Deban L (2012) Determination of ascorbic acid in commercial juices, on a modified carbon paste electrode, by using a Taguchi experimental design. Food Anal Methods 5:441-447

Wang Z, Cui H, Xia J, Han Q, Lv N, Gao J, Guo X, Zhang F, Ma J, Su G (2013) A novel method for bisphenol A analysis in dairy products using graphene as an adsorbent for solid phase extraction followed by ion chromatography. Food Anal Methods 6:1537-1543

Wang L, Zang X, Chang Q, Zhang G, Wang C, Wang Z (2014) Determination of triazole fungicides in vegetable samples by magnetic solid-phase extraction with graphene-coated magnetic nanocomposite as adsorbent followed by gas chromatography-mass spectrometry detection. Food Anal Methods 7:318-325

Wonsawat W, Chuanuwatanakul S, Dungchai W, Punrat E, Motomizu S, Chailapakul O (2012) Graphene-carbon paste electrode for cadmium and lead ion monitoring in a flow-based system. Talanta 100: 282-289

Wu J, Qian Y, Zhang C, Zheng T, Chen L, Lu Y, Wang H (2013) Application of graphene-based solid-phase extraction coupled with ultra high-performance liquid chromatography-tandem mass spectrometry for determination of macrolides in fish tissues. Food Anal Methods 6:1448-1457

Yang X, Yuan J, Man PZ, Niu XJ, Zheng T (2011) Differential pulse stripping voltammetry determination of trace lead in water using Au-graphene sheets modified carbon paste electrode. Metall Anal 31:46-50

Zhang YB, Tan YW, Stormer HL, Kim P (2005) Experimental observation of the quantum hall effect and Berry's phase in graphene. Nature 438:201-204. doi:10.1038/Nature04235

Zhao JP, Pei SF, Ren WC, Gao LB, Cheng HM (2010) Efficient preparation of large-area graphene oxide sheets for transparent conductive films. ACS Nano 4:5245-5252

Zmozinski AV, Passos LD, Damin ICF, Espirito Santo MAB, Vale MGR, Silva MM (2013) Determination of cadmium and lead in fresh fish samples by direct sampling electrothermal atomic absorption spectrometry. Anal Methods 5:6416-6424 